\title{
Use of Medicines by Infants with Microcephaly Caused by Congenital Zika Virus Infection and Implications to Oral Health
}

\author{
Alessandro Leite Cavalcanti1 ${ }^{\circledR}$, Taynná Dantas de Arruda ${ }^{\circledR}$, Liege Helena Freitas Fernandes ${ }^{1}$, \\ Jeime Iara Bezerra de Freitas Leal ${ }^{3}$, , Yeska Paola Costa Aguiar ${ }^{1}$, , Sergio D’Avila Lins Bezerra

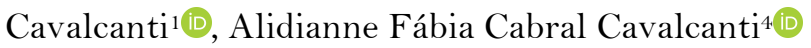

${ }^{1}$ Post-graduate Program in Dentistry, Department of Dentistry, State University of Paraíba, Campina Grande, PB, Brazil.

${ }^{2}$ School of Dentistry, State University of Paraíba, Araruna, PB, Brazil.

${ }^{3}$ Specialized Rehabilitation Center, Campina Grande, PB, Brazil.

${ }^{4}$ Department of Dentistry, State University of Paraíba, Campina Grande, PB, Brazil.

Author to whom correspondence should be addressed: Prof. Alessandro Leite Cavalcanti, Universidade Estadual da Paraíba, Departamento de Odontologia, Rua das Baraúnas, 351, Bairro Universitário, Campina Grande, PB, Brazil. 58429-500. Phone: +55 83 3315-3326. E-mail: alessandrouepb@gmail.com.

Academic Editors: Alessandro Leite Cavalcanti and Wilton Wilney Nascimento Padilha

Received: 22 October 2019 / Accepted: 05 March 2020 / Published: 18 March 2020

How to cite this article: Cavalcanti AL, Arruda TD, Fernandes LHF, Leal JIBF, Aguiar YPC, Cavalcanti SDLB, et al. Use of medicines by infants with microcephaly caused by congenital zika virus infection and implications to oral health. Pesqui Bras Odontopediatria Clín Integr. 2020; 20:e5565. https://doi.org/10.1590/pboci.2020.048

\footnotetext{
Abstract

Objective: To analyze the use of continued-use medications by Brazilian children with microcephaly caused by Congenital Zika Virus Infection. Material and Methods: Cross-sectional study with 76 children of both genders. Information on age, use of continued-use medications, number and type of drugs used was collected. Data were analyzed using descriptive statistics. Results: Continued-use medications were used by $89.4 \%$ of the children, anticonvulsants / antiepileptics $(88.1 \%)$, and those indicated for behavioral disorders $(27.1 \%)$ were the most frequent. Sodium saccharin, sucrose, and sorbitol are the most common sugars in the composition of these drugs. Conclusion: The use of medicines is high, predominantly anticonvulsants and antiepileptics, which contain sugars in their composition. These drugs can lead to irreversible dental problems, such as tooth decay if proper oral hygiene is not present. Therefore, parents/guardians should be advised about adopting healthy oral hygiene habits after the administration of these drugs.

Keywords: Microcephaly; Child; Prescription Drugs; Oral Health.
} 


\section{Introduction}

The first description of the Zika virus was made in Uganda in 1947 in the Zika Valley. It is a mild disease with fever, erythema, and arthralgia [1]. As there is no known medical treatment for this disease, a serious attempt has been needed to eradicate the mosquito and prevent the spread of the disease to other Brazilian states and across the border [2].

According to the National Institute of Neurological Disorders and Stroke (NINDS), "microcephaly is a medical condition in which the circumference of the head is smaller than normal because the brain has not developed properly or has stopped growing" [3]. Microcephaly can be present at birth or it may develop in the first few years of life [4].

In Brazil, "thousands of cases of infants with suspected microcephaly or other developmental anomalies of the central nervous system that may be associated with ZIKV infection have been reported" [5]. Paraíba is the state with the second-highest number of suspected cases of microcephaly. Most of those were born into low-income families that reported difficulties in accessing medicine and attention from the public health system [6].

There are several studies that warn of the deleterious effects of drugs on primary teeth, due to the presence of sugars in the composition of these drugs [7-9]. This study aimed to describe the usage of continued-use drugs by children with microcephaly caused by congenital zika syndrome (CZS) and the possible implications for oral health.

\section{Material and Methods}

Design and Study Location

This cross-sectional study was conducted in the city of Campina Grande, State of Paraíba, northeastern Brazil. The research was developed in one rehabilitation center that offers assistance to children with congenital zika syndrome, providing physical, intellectual, auditory and visual rehabilitation treatment.

Sampling

The sample consisted of 76 children with confirmed diagnosis of microcephaly of both sexes, attended at the Specialized Center for Rehabilitation.

\section{Data Collection}

Through a questionnaire, information was collected by two researchers from September 2016 to April 2017 regarding the demographic situation and continued-use medicine treatments.

\section{Data Analysis}

Data were organized and analyzed with Statistical Package for Social Sciences, Version 21.0 (IBM Corporation, Chicago, IL, USA) using descriptive statistics.

Ethical Aspects

This study was approved by the Human Research Ethics Committee of the State University of Paraíba in compliance with Brazilian National Health Council Resolution 466/12. All parents received information 
regarding the objectives of the study and provided written informed consent regarding their child's participation.

\section{Results}

Most of the children were female (53.9\%), aged between 13 and 24 months (81.6\%). The average age was 21.1 months ( $\mathrm{SD} \pm 4.8$ ), minimum of 8 months, and a maximum of 38 months.

Continued-use medications were confirmed in $85.9 \%$ of the children, with most using only one medication $(41.0 \%)$. The average medication per child was $1.7( \pm 1.2)$. The most commonly used medications were Anticonvulsant/Antiepileptic (85.9\%) (Table 1).

Table 1. Distribution of children according to continued-use medication and type of substance.

\begin{tabular}{|c|c|c|}
\hline Variables & $\mathbf{N}$ & $\%$ \\
\hline \multicolumn{3}{|l|}{ Sex } \\
\hline Male & 35 & 46.1 \\
\hline Female & 41 & 53.9 \\
\hline \multicolumn{3}{|l|}{ Age (in months) } \\
\hline Up to 12 & 4 & 5.3 \\
\hline 13 to 24 & 62 & 81.6 \\
\hline 25 to 38 & 10 & 13.2 \\
\hline \multicolumn{3}{|c|}{ Continued-use Medications } \\
\hline Yes & 61 & 85.9 \\
\hline No & 10 & 14.1 \\
\hline \multicolumn{3}{|c|}{ Number of Medications Utilized } \\
\hline 1 & 25 & 41.0 \\
\hline 2 & 21 & 34.4 \\
\hline 3 & 8 & 13.1 \\
\hline 4 & 5 & 8.2 \\
\hline 5 & 2 & 3.3 \\
\hline \multicolumn{3}{|c|}{ Type of Medication Utilized } \\
\hline \multicolumn{3}{|c|}{ Anticonvulsant/Antiepileptic } \\
\hline Yes & 53 & 86.9 \\
\hline No & 8 & 13.1 \\
\hline \multicolumn{3}{|l|}{ Antispastic } \\
\hline Yes & 16 & 26.2 \\
\hline No & 45 & 73.8 \\
\hline \multicolumn{3}{|l|}{ Sedative/Anxiolytic } \\
\hline Yes & 6 & 9.8 \\
\hline No & 55 & 90.2 \\
\hline \multicolumn{3}{|l|}{ Behavior Disorder } \\
\hline Yes & 16 & 26.2 \\
\hline No & 45 & 73.8 \\
\hline
\end{tabular}

Table 2 presents the composition and possible oral implications of the medications used. Among the sugars/sweeteners are sodium saccharin, sucrose, and sorbitol. Other substances, such as cornstarch and essences, are also present. As for the oral implications described in the leaflets are dry mouth, vomiting, dysgeusia, changes in taste, trismus and sialorrhea. Of particular note are the complications from using an antiepileptic drug for children over 1 month of age: swelling of the lips, throat or mouth; difficulty speaking or swallowing; blisters on the mucous membranes of the lips and mouth; mouth ulcers and vomiting. 
Table 2. Distribution of the medications according to composition, class and oral implications.

\begin{tabular}{|c|c|c|c|c|c|c|c|}
\hline $\begin{array}{l}\text { Commercial } \\
\text { Name }\end{array}$ & Active Principle & Composition & Drug Class & Form & Manufacturer & $\begin{array}{c}\text { Oral } \\
\text { Implications }\end{array}$ & $\begin{array}{l}\text { Pediatric } \\
\text { Use }\end{array}$ \\
\hline Baclon & Baclofen & $\begin{array}{l}\text { Starch, Lactose } \\
\text { Monohydrate }\end{array}$ & Antispastic & Tablet & Genomma Lab. & $\begin{array}{l}\text { Myalgias, Dry Mouth, } \\
\text { Vomiting, Dysgeusia }\end{array}$ & No \\
\hline Baclofen & Baclofen & Starch, Lactose & Antispastic & Tablet & $\begin{array}{l}\text { Laboratório Teuto } \\
\text { Brasileiro S.A }\end{array}$ & - & No \\
\hline Rivotril & Clonazepam & Lactose, Corn Starch & Anxiolytic & Tablet & Roche & Dysarthria & Yes \\
\hline Tegretol & Carbamazepine & $\begin{array}{c}\text { Caramel Flavor, Sodium } \\
\text { Saccharin Dihydrate, } \\
\text { Sorbitol }\end{array}$ & Antiepileptics & Tablet & Medley & $\begin{array}{c}\text { Changes in Taste, Disjointed } \\
\text { Speech }\end{array}$ & Yes \\
\hline $\begin{array}{l}\text { Frisium, } \\
\text { Urbanil }\end{array}$ & Clobazam & $\begin{array}{l}\text { Corn Starch, Lactose } \\
\text { Monohydrate }\end{array}$ & Anxiolytic & Tablet & Sanofi & - & $\begin{array}{l}\text { Yes, above } 3 \text { years } \\
\text { of age }\end{array}$ \\
\hline Depakene & Valproic Acid & Sacarose, Sorbitol & Anticonvulsant & Oral Solution & Abbott Laboratórios & Vomiting & $\begin{array}{l}\text { Yes, preferentially } \\
\text { above } 2 \text { years of age }\end{array}$ \\
\hline Fenoarbital & Phenobarbital & $\begin{array}{l}\text { Lactose Monohydrate, } \\
\text { Amido }\end{array}$ & Anticonvulsant & Tablet & Teuto & Difficulty Speaking & No \\
\hline Gardenal & Phenobarbital & $\begin{array}{l}\text { Sodium Saccharin } \\
\text { Dihydrate, } \\
\text { Raspberry Essence }\end{array}$ & Anticonvulsant & $\begin{array}{l}\text { Oral Solution } \\
\text { (Drops) }\end{array}$ & Sanofi & Difficulty Speaking & $\begin{array}{l}\text { Yes, oral pediatric } \\
\text { use }\end{array}$ \\
\hline Keppra & Levetiracetam & - & Antiepileptic & Tablet & Biopharma & Myalgias & $\begin{array}{c}\text { Yes, above } 6 \text { years } \\
\text { of age }\end{array}$ \\
\hline Lamictal & Lamotrigine & $\begin{array}{l}\text { Starch, Sodium Starch } \\
\text { Glycolate }\end{array}$ & Antiepileptic & Tablet & Teuto & Vomiting & $\begin{array}{c}\text { Yes, above } 12 \text { years } \\
\text { of age }\end{array}$ \\
\hline Neuleptil & Periciazine & $\begin{array}{c}\text { Liquid Sucrose, Caramel, } \\
\text { Mint Essence }\end{array}$ & Antipsychotic & Oral Solution & Sanofi & Dry Mouth, Trismus & $\begin{array}{c}\text { Yes, above } 3 \text { years } \\
\text { of age }\end{array}$ \\
\hline Sabril & Vigabatrin & Sodium Starch Glycolate & Antiepileptic & Tablet & Sanofi Aventis & Vomiting & Yes \\
\hline Sonebon & Nitrazepam & $\begin{array}{l}\text { Lactose Monohydrate, } \\
\text { Aluminum Red Lacquer } \\
\text { Erythrosine } 3\end{array}$ & $\begin{array}{l}\text { Sedative } \\
\text { Hypnotic }\end{array}$ & Tablet & $\begin{array}{c}\text { Ems Sigma Pharma } \\
\text { Ltda }\end{array}$ & $\begin{array}{l}\text { Dysarthria, Sialorrhea, } \\
\text { Vomiting, Dry Mouth }\end{array}$ & No \\
\hline Tegretol & Carbamazepine & $\begin{array}{c}\text { Sorbitol, Sodium } \\
\text { Saccharin, Caramel } \\
\text { Flavor }\end{array}$ & Anticonvulsant & Oral Suspension & Novartis & Speech Disorders & Yes \\
\hline Topamax & Topiramate & $\begin{array}{l}\text { Lactose Monohydrate, } \\
\text { Starch, Sodium Starch } \\
\text { Glycolate }\end{array}$ & Anticonvulsant & Tablet & Sandoz & $\begin{array}{c}\text { Increased Salivation, Speech } \\
\text { Disorders }\end{array}$ & Yes \\
\hline Trileptal & Oxcarbazepine & - & Antiepileptics & Tablet & Novartis & $\begin{array}{l}\text { Swelling of the Lips, Throat or } \\
\text { Mouth, Difficulty Speaking or } \\
\text { Swallowing, Blisters on the } \\
\text { Mucous Membranes of the lips } \\
\text { and Mouth, Mouth Ulcers, } \\
\text { Vomiting }\end{array}$ & $\begin{array}{l}\text { Yes, above } 1 \text { month } \\
\text { of age }\end{array}$ \\
\hline
\end{tabular}




\section{Discussion}

In most cases of microcephaly, there is severe neurological damage that can result in impaired cognition and motor coordination. Therefore, episodes of epileptic seizures and mood swings are common, leading children with microcephaly, even at an early age, to use continued-use medications [10].

Children with special needs are mostly dependent on their caregivers for their daily living activities $[9,11]$, including tooth brushing. Parents and/or caregivers of children with microcephaly have an intense routine of therapies, which often occur in different places and may compromise the persistence and routine necessary to perform oral hygiene [12]. Added to this is the low age of most of the children in this study ( $81.6 \%$ of them were 13 to 24 months old), which can potentiate these oral hygiene difficulties.

Children with microcephaly have delayed eruption chronology, altered tooth eruption sequence [1214], altered muscle tone, with consequences for suction, swallowing, lip seal, and mouth breathing [9]. Literature has also mentioned a higher prevalence of enamel defects, which entails a higher risk of dental caries [13].

Analysis of the drug leaflets revealed that anticonvulsants and antiepileptics, the class of drugs most commonly administered by the children in the study, can cause vomiting. At these times, intrinsic acids in the organism, present in the gastric juice, are taken to the oral cavity through the atypical flow of content from the stomach [15], and this is responsible for making the dental surface soft and susceptible to abrasion and friction wear [16]. Because of the higher risk of dental erosion development in these cases, the constant monitoring of the children who use this type of medication by a dentist is recommended.

Special attention is advised to possible oral symptoms resulting from the use of Trileptal ${ }^{\circledR}$, an antiepileptic medicine that, in addition to inducing vomiting, may cause swelling of the lips, throat or mouth, difficulty to speak or swallow, blistering of mucous membranes of the lips and mouth, and mouth ulcers, which can negatively affect the quality of life of these children.

More than half of the children use more than one drug, possibly due to the number of sequelae resulting from neurological damage, such as visual alterations, speech and hearing disorders, hypertonia, intracranial calcifications, choroid plexus enlargement, ventriculomegaly, and hydrocephalus [13]. Therefore, it is cautioned that undesirable oral effects may be added to children exposed to more than one drug.

Most pediatric drugs contain high levels of sucrose [7,9]. The analysis of the leaflets reveals that this substance is present in the composition of the medications administered to the children in this study. The addition of sucrose improves palatability, favoring acceptance and continuity of the children; sucrose also has preservative, antioxidant, solvent and thickening properties [17]. Children who use this substance are exposed to a cumulative harmful effect, which can manifest as carious lesions [18].

Recommendation to immediately rinse in water and delay tooth-brushing after ingestion of syrup medications could be proposed at the time of prescription. Previous authors reported that "medicine labels should also alert in relation to the possibility of causing dental caries and erosion since many products could be consumed for prolonged periods, several times a day, at bedtime, and without adequate oral hygiene, which would certainly contribute to dental caries and erosion" [19].

Microcephaly is a condition that causes numerous problems in children's health; so knowing which medications are used is extremely relevant. Therefore, dentists should be aware of sugars in child medicine and the parents should be informed of the need for proper oral hygiene after medication administration. 


\section{Conclusion}

The use of medicines that contain sugars in their composition is high, predominantly anticonvulsants and antiepileptics. These drugs can lead to irreversible dental problems, such as tooth decay if proper oral hygiene is not present. Therefore, parents/guardians should be advised about adopting healthy oral hygiene habits after the administration of these drugs.

\section{Authors' Contributions}

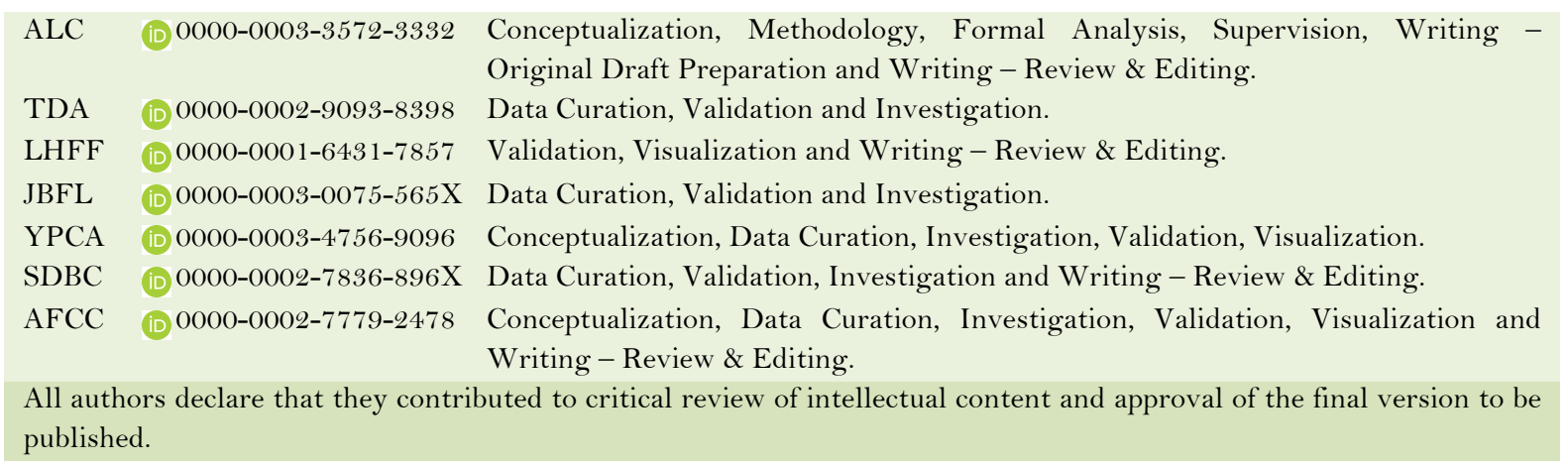

\section{Financial Support}

Brazilian National Council for Scientific and Technological Development (CNPq) - Research Productivity Grant (Process $302850 / 2016-3)$.

\section{Conflict of Interest}

The authors declare no conflicts of interest.

\section{References}

[1] Besnard M, Lastere S, Teissier A, Cao-Lormeau V, Musso D. Evidence of perinatal transmission of Zika virus, French Polynesia, December 2013 and February 2014. Euro Surveill 2014; 19(13). pii: 20751.

[2] Goenaga S, Kenney JL, Duggal NK, Delorey M, Ebel GD, Zhang B, et al. Potential for co-infection of a mosquitospecific flavivirus, nhumirim virus, to block West Nile virus transmission in mosquitoes. Viruses 2015; 7(11):5801-12. https://doi.org/10.3390/v7112911

[3] National Institute of Neurological Disorders and Stroke. Microcephaly Information Page. Available from: https://www.ninds.nih.gov/disorders/all-disorders/microcephaly-information-page. [Accessed on October 21, 2019].

[4] Passemard S, Kaind AM, Verloes A. Microcephaly. Handb Clin Neurol 2013; 111:129-41. https://doi.org/10.1016/B978-0-444-52891-9.00013-0

[5] Johansson MA, Mier-y-Teran-Romero L, Reefhuis J, Gilboa SM, Hills SL. Zika and the risk of microcephaly. N Engl J Med 2016; 375(1):1-4. https://doi.org/10.1056/NEJMp1605367

[6] Collucci C. Babies with microcephaly in Brazil are struggling to access care. BMJ 2016; 355:16157. https://doi.org/10.1136/bmj.i6157

[7] Xavier AFC, Abreu MHNG, Melo JBCA, Anselmo GCS, Cavalcanti AL. Changes in microhardness and morphology of the adamantine structure as a function of the exposure time to different drugs. Pesqui Bras Odontopediatria Clín Integr 2015; 15(1):279-89. https://doi.org/10.4034/PBOCI.2015.151.30

[8] Cavalcanti AL, Vieira FF, Souto RQ, Xavier AFC, Cavalcanti CL. In vitro evaluation of different physicochemical properties of pediatric medicines. Pesqui Bras Odontopediatria Clín Integr 2013; 13(1):69-75. https://doi.org/10.4034/PBOCI.2013.131.10

[9] Hartwig AD, Ferreira LM, Costa FS, Cademartori MG, Goettems ML, Schardosim LR. Experience of dental caries and use of continuous medication in children with neuropsychomotor disorders. Pesqui Bras Odontopediatria Clín Integr 2016; 16(1):59-67. https://doi.org/10.4034/PBOCI.2016.161.07

[10] Cavalcanti AL. Challenges of dental care for children with microcephaly carrying Zika congenital syndrome. Contemp Clin Dent 2017; 8(3):345-6. https://doi.org/10.4103/0976-237X.214553 
[11] Medeiros MMD, Martins ML, Gomes LN, Cardoso AMR, Padilha WWN, Cavalcanti AL. Factors associated with the caregivers' perception of the oral health of individuals with cerebral palsy. Pesqui Bras Odontopediatria Clín Integr 2019; 19:e4824. https://doi.org/10.4034/pboci.2019.191.139

[12] Aguiar YPC, Cavalcanti AFC, Alencar CRB, Melo ASO, Cavalcanti SDLB, Cavalcanti AL. Chronology of the first deciduous tooth eruption in Brazilian children with microcephaly associated with Zika virus: a longitudinal study. Pesqui Bras Odontopediatria Clín Integr 2018; 18(1):e3982. https://doi.org/10.4034/PBOCI.2018.181.16

[13] Siqueira RMP, Santos MTBR, Cabral GMP. Alterations in the primary teeth of children with microcephaly in Northeast Brazil: a comparative study. Int J Paediatr Dent 2018; 28(5):523-32. https://doi.org/10.1111/ipd.12402

[14] Cavalcanti AFC, Aguiar YPC, de Oliveira Melo AS, de Freitas Leal JIB, Cavalcanti AL, Cavalcanti SDLB. Teething symptoms in children with congenital Zika syndrome: a 2-year follow-up. Int J Paediatr Dent 2019; 29(1):74-8. https://doi.org/10.1111/ipd.12431

[15] Shellis RP, Addy M. The interactions between attrition, abrasion and erosion in tooth wear. Monogr Oral Sci 2014; 25:32-45. https://doi.org/10.1159/000359936

[16] Wiegand A, Wegehaupt F, Werner C, Attin T. Susceptibility of acid-softened enamel to mechanical wear ultrasonication versus toothbrushing abrasion. Caries Res 2007; 41(1):56-60. https://doi.org/10.1159/000096106

[17] Nirmala SV, Popuri VD, Chilamakuri S, Nuvvula S, Veluru S, Minor Babu MS. Oral health concerns with sweetened medicaments: pediatricians' acuity. J Int Soc Prev Community Dent 2015; 5(1):35-9.

https://doi.org/10.4103/2231-0762.151973

[18] Xavier AF, Moura EF, Azevedo WF, Vieira FF, Abreu MH, Cavalcanti AL. Erosive and cariogenicity potential of pediatric drugs: study of physicochemical parameters. BMC Oral Health 2013; $13: 71$.

https://doi.org/10.1186/1472-6831-13-71

[19] Valinoti AC, da Costa LC Jr, Farah A, Pereira de Sousa V, Fonseca-Gonçalves A, Maia LC. Are pediatric antibiotic formulations potential risk factors for dental caries and dental erosion? Open Dent J 2016; 10:420-30. https://doi.org/10.2174/1874210601610010420 